\title{
Drinking Water Arsenic and Adverse Reproductive Outcomes in Men and Women: A Systematic PRISMA Review
}

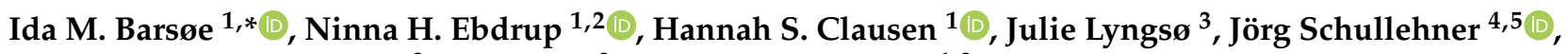 \\ Cecilia H. Ramlau-Hansen ${ }^{3}$, Bjørn Bay ${ }^{2}$ and Ulla B. Knudsen ${ }^{1,2}$ \\ 1 Department of Clinical Medicine, Aarhus University, 8200 Aarhus N, Denmark; \\ ida.barsoee@gmail.com (I.M.B.); ninebd@clin.au.dk (N.H.E.); hannahsvinth@gmail.com (H.S.C.); \\ ullaknud@rm.dk (U.B.K.) \\ 2 Department of Obstetrics and Gynecology, Fertility Clinic, Horsens Regional Hospital, 8700 Horsens, \\ Denmark; bjornbay@me.com (B.B.) \\ 3 Department of Public Health, Research Unit for Epidemiology, Aarhus University, 8000 Aarhus C, Denmark; \\ jlyn@ph.au.dk (J.L.); chrh@ph.au.dk (C.H.R.-H.) \\ 4 Department of Public Health, Research Unit for Environment, Work and Health, Aarhus University, \\ 8000 Aarhus C, Denmark; jorg.schullehner@ph.au.dk (J.S.) \\ 5 Geological Survey of Denmark and Greenland (GEUS), 8000 Aarhus C, Denmark \\ * Correspondence: ida.barsoee@gmail.com
}

check for

updates

Citation: Barsøe, I.M.; Ebdrup, N.H.; Clausen, H.S.; Lyngsø, J.; Schullehner, J.; Ramlau-Hansen, C.H.; Bay, B.; Knudsen, U.B. Drinking Water Arsenic and Adverse Reproductive Outcomes in Men and Women: A Systematic PRISMA Review. Water 2021, 13, 1885. https://doi.org/ 10.3390/w13141885

Academic Editor: Domenico Cicchella

Received: 24 May 2021

Accepted: 25 June 2021

Published: 7 July 2021

Publisher's Note: MDPI stays neutral with regard to jurisdictional claims in published maps and institutional affiliations.

Copyright: (c) 2021 by the authors. Licensee MDPI, Basel, Switzerland. This article is an open access article distributed under the terms and conditions of the Creative Commons Attribution (CC BY) license (https:// creativecommons.org/licenses/by/ $4.0 /)$.
Abstract: Infertility is a worldwide health issue, but mechanisms of both male and female reproductive toxicity remain to be elucidated. So far, a limited focus has been on potentially harmful environmental factors such as arsenic, which is naturally occurring in groundwater. The objective of this review was to systematically investigate the association between arsenic in drinking water and adverse reproductive outcomes in men and women of fertile age. We conducted a systematic literature search and included case-control studies and cohort studies reporting on decreased semen quality characteristics, increased time to pregnancy, infertility, or spontaneous abortion. In total, 433 articles were screened and ultimately, eight studies were included. Included literature was quality assessed with the Newcastle-Ottawa Scale. Findings were reported in a narrative synthesis. Only one study investigated male fertility. An association between increasing arsenic exposure and decreasing semen quality characteristics was found, as well as an indication of arsenic accumulation in seminal plasma. These findings are, however, at high arsenic levels $(>1000 \mu \mathrm{g} / \mathrm{L})$. No consistent evidence was found to support the hypothesis that arsenic exposure from drinking water is a cause of longer waiting time to pregnancy or spontaneous abortion, being the only endpoints investigated in the included literature. In conclusion; the evidence is sparse and of varying quality, however, it does warrant attention, as it conflicts with existing evidence, mainly from cross-sectional or ecologic studies.

Keywords: arsenic; drinking water; infertility; reproductive outcome; semen quality; spontaneous abortion

\section{Introduction}

Infertility and subfecundity are worldwide health issues with one in six couples experiencing fertility problems during their reproductive age [1,2]. Further, approximately $30 \%$ of all pregnancies terminate in spontaneous abortions [3]. Consequently, efforts to identify potential causes of adverse reproductive outcomes are necessary. Mechanisms of both male and female reproductive toxicity remain to be elucidated, yet only a minority of studies have focused on the role of environmental factors.

Arsenic is a common pollutant in groundwater-based drinking water supply systems worldwide, partly due to anthropogenic sources, but mainly by natural occurrence [4,5]. Arsenic exists in an organic or inorganic form (iAs), the latter of which is classified as a group 1 carcinogen $[4,6]$ and is known to cause a wide range of adverse health outcomes such as skin lesions [7], vascular diseases [8,9] and neurodevelopmental problems [10]. 
Arsenic easily crosses the human placental barrier [11], and several epidemiological studies, mainly of ecological or cross-sectional design, have found associations between exposure to high-level arsenic and risks of spontaneous abortion, stillbirth and low birth weight [12]. Possible mechanisms have been suggested from animal studies, where prenatal arsenic exposure has resulted in defective implantation, zygote development and disrupted placental vasculogenesis $[13,14]$.

The existing literature based on human studies that have investigated the possible reproductive toxicity of arsenic in men is limited. Studies are primarily from ecological or cross-sectional design and results are equivocal [15-21]. In animal studies, however, significantly lower testicular, epididymal and prostate weight, as well as significantly lower sperm motility and epididymal sperm count when exposed to arsenic through drinking water have been reported [22-24]. Additionally, it has been observed that the process of sperm capacitation and sperm-egg fusion is repressed, leading to defective fertilisation [25].

The World Health Organization (WHO) has recognised the harmfulness of arsenic and set out a provisional guideline value of $10 \mu \mathrm{g} / \mathrm{L}$, however, stressing that "every effort should be made to keep concentrations as low as reasonably possible" [6]. Yet, this guideline value is based on the carcinogenic effect and does not consider any potential reproductive toxicity.

Therefore, the aim of this systematic review was to investigate if exposure to arsenic through drinking water is associated with adverse reproductive outcomes in men and women of fertile age.

\section{Materials and Methods}

This systematic review follows the Preferred Reporting Items for Systematic Reviews and Meta-Analyses (PRISMA) statement [26], and a flowchart has been made to report the inclusion/exclusion and characteristics of all included studies (see Figure 1). 

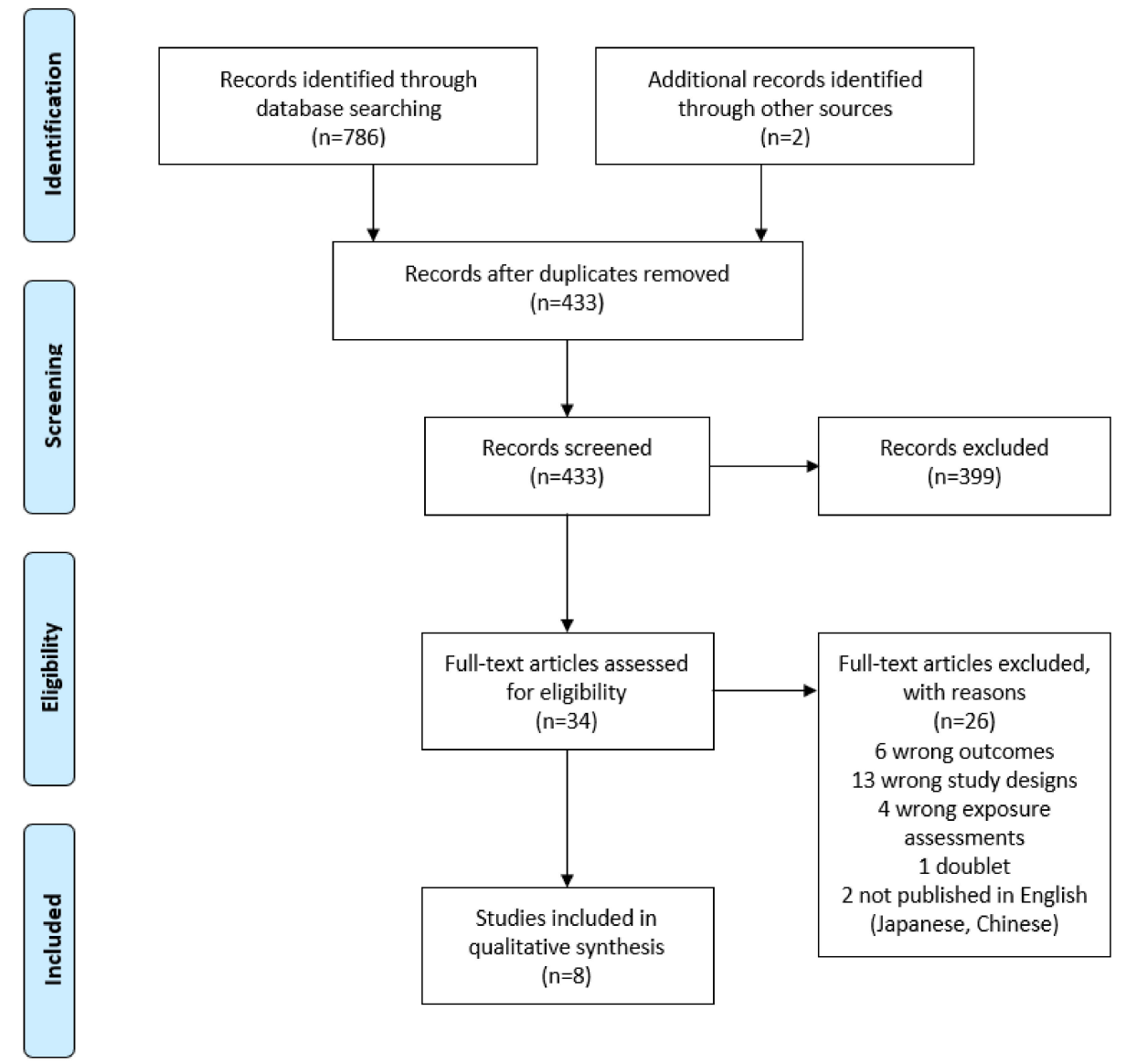

Figure 1. Flowchart for selection of included literature.

A review protocol is available from the PROSPERO database [27] with registration number CRD42019138503.

\subsection{Search Strategy and Study Selection}

A comprehensive systematic literature search was carried out in the electronic databases PubMed/Medline, Embase and Scopus on 24 May 2019. The full search strategy is available in the Supplementary Materials. To identify potentially relevant studies, keywords, medical subject headings (MeSH) and Emtree terms were used. To ensure the inclusion of non-indexed, new literature, a free-text search was performed, and the bibliographies of included studies were hand-searched to retrieve additional studies.

All literature describing exposure to arsenic in drinking water associated with adverse reproductive outcomes in men and women of fertile age was assessed. The focus was on infertility and subfecundity (e.g., semen quality parameters, extended time to pregnancy (TTP) or assisted reproductive technologies (ART)) and pregnancy complications (i.e., spontaneous abortion) that could be an indirect measurement of infertility. All identified studies were screened by title and abstract for eligibility; potentially relevant studies were obtained and read in full text and critically evaluated for inclusion by two authors. Inclusion criteria:

1. Studies containing a relevant population:

- Women of fertile age (15-51 years)

- $\quad$ Men of fertile age (15-65 years)

2. Studies assessing arsenic exposure from drinking water

3. Studies containing a relevant control group

4. Studies investigating at least one of the following outcomes:

- Infertility (including extended TTP, ART, and menstrual disturbances)

- Semen quality parameters 
- Pregnancy complications (i.e., spontaneous abortion)

5. Original studies

6. Studies with one of the following designs:

- Cohort study

- Case-control study

7. Studies published in the English language

Studies not meeting these criteria were excluded.

The electronic database search was repeated on 13 November 2019, and no new literature was deemed eligible for inclusion.

\subsection{Data Extraction and Quality Assessment}

To ensure a standardised procedure, an a priori data extraction form was used to retrieve information from all included studies (available in Supplementary Materials). The quality of the included studies was assessed using the Newcastle-Ottawa Scale (NOS) [28] by two independent authors. In case of disagreement, a consensus was reached by discussion, or if necessary, by consulting a third reviewer. An explanatory form was made for the NOS to secure a standardised scoring (available in Supplementary Materials). The most important covariates were chosen to be maternal age for women and smoking for men. Studies were allocated a score between 0 and 9 . The studies with a score of 7 or above were considered high-quality studies and were subsequently considered separately to see if this had any impact on the conclusion of this systematic review. No authors, investigators, or alike were contacted to obtain missing information, neither were protocols for included studies obtained.

\section{Results}

The total number of potentially relevant studies found through database and bibliography searches was 786 (see Figure 1). All relevant studies were obtained and accounted for. Eight studies were deemed eligible for inclusion in the systematic review.

Study characteristics, results and the assigned NOS-score from the quality assessment are presented in Tables 1 and 2.

\subsection{Women}

Seven of the included studies reported reproductive outcomes in women, one study reported on the association with TTP [29], and six reported on associations with spontaneous abortion [30-35], however, two of these presented pooled results of fetal losses $[30,35]$.

\subsubsection{High-Level Arsenic Exposure (Above $10 \mu \mathrm{g} / \mathrm{L}$ )}

The studies conducted in areas with high levels of arsenic in the drinking water, measured exposure through drinking water solely or in both drinking water and urine. Of the four studies measuring arsenic exposure directly in drinking water, two studies, namely Banu [32] et al. and Mukherjee et al. [34], only reported the incidence of spontaneous abortion in the study period and made no further analysis. The remaining two reported either a combined outcome defined as fetal loss, Ahmed et al. [30] or considered early fetal loss (i.e., spontaneous abortion) separately but pooled the results in the analysis, Rahman et al. [35]. Ahmed et al. [30] conducted a cohort study with prospectively collected exposure data with 1616 participants and found no statistically significant difference in the occurrence of fetal loss among exposure groups but reported a non-linear exposure-response relationship varying across the pregnancy. Additionally, they measured urinary markers to assess arsenic exposure and found similar results. Rahman et al. [35], who conducted a large cohort study with prospectively collected exposure data with 29,132 participants, reported a tendency of increased risk of fetal loss for higher quintiles of water arsenic concentration. However, this was only statistically significant for the highest quintile (arsenic concentration $\geq 409 \mu \mathrm{g} / \mathrm{L}$ ) compared with the lowest quintile (arsenic concentration $<10 \mu \mathrm{g} / \mathrm{L}$ ). 


\subsubsection{Low to Moderate Arsenic Exposure (Below $10 \mu \mathrm{g} / \mathrm{L}$ )}

Three studies investigated a potential association between low to moderate levels of arsenic exposure and adverse reproductive outcomes [29,31,33]. The comparison was, however, somewhat difficult since they did not report on the same outcome. As the only study reporting on TTP, Susko et al. [29] found modestly lowered pregnancy probabilities for women with extended TTP, with higher arsenic exposure, but overall, they did not find any association between low-level arsenic in drinking water and women's fecundity in their cohort study with retrospectively collected exposure data. Neither of the two studies reporting pregnancy outcomes found any convincing evidence of increased risk of spontaneous abortion. In a case-control study with 1677 participants, Aschengrau et al. [31] found a weak statistically non-significant association, whereas Bloom et al. [33] found no increased risk in their case-control study with 300 participants. 


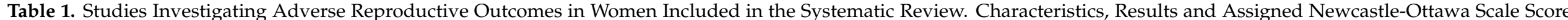
are Presented.

\begin{tabular}{|c|c|c|c|c|c|c|c|c|}
\hline $\begin{array}{l}\text { Author, Year, } \\
\text { Country }\end{array}$ & Study Design & $\begin{array}{l}\text { Study Population } \\
\text { (Size and Selection) }\end{array}$ & Exposure Assessment & Outcome & $\begin{array}{c}\text { Confounding } \\
\text { Control }\end{array}$ & Main Results ${ }^{1}$ & $\begin{array}{l}\text { Effect of } \\
\text { Arsenic } \\
\text { Exposure }^{2}\end{array}$ & $\begin{array}{c}\text { Total } \\
\text { NOS-Score }\end{array}$ \\
\hline $\begin{array}{c}\text { Ahmed et. al., } \\
\text { 2019, } \\
\text { Bangladesh }\end{array}$ & $\begin{array}{l}\text { Cohort study, } \\
\text { prospectively } \\
\text { collected } \\
\text { information on } \\
\text { exposure }\end{array}$ & $\begin{array}{c}\text { Total: } 1616 \text { pregnant } \\
\text { women } \\
\\
\text { Case: } 203 \text { Women with } \\
\text { fetal loss } \\
\text { Comparison: Women } \\
\text { with completed } \\
\text { pregnancy }\end{array}$ & $\begin{array}{c}\text { 1st quartile: } 0.05-0.89 \mu \mathrm{g} / \mathrm{L} \\
\text { 2nd quartile: } 0.09-2.00 \mu \mathrm{g} / \mathrm{L} \\
\text { 3rd quartile: } 2.10-34.00 \mu \mathrm{g} / \mathrm{L} \\
\text { 4th quartile: } \\
\text { 45.00-1400.00 } \mu \mathrm{g} / \mathrm{L} \\
\text { Urinary arsenic } \\
\text { concentrations (not specified) }\end{array}$ & $\begin{array}{l}\text { Fetal loss (a fetus } \\
\text { that never } \\
\text { showed signs of } \\
\text { life outside the } \\
\text { womb) }\end{array}$ & $\begin{array}{c}\text { Maternal age (18-34 } \\
\text { years and }>35 \text { years }) \\
\text { Monthly family } \\
\text { income } \\
\text { Educational level } \\
\text { Gravidity } \\
\text { Clinic location }\end{array}$ & $\begin{array}{l}\text { No significant difference in the } \\
\text { occurrence of fetal loss amongst the } \\
\text { four exposure groups } \\
\text { ( } p \text {-value }=0.208) \\
\text { A non-linear exposure-response } \\
\text { relationship, varying across the } \\
\text { pregnancy } \\
\text { Gestational age } 9-12 \text { (lowest HR): } \\
\text { HR }=0.81 \text { (95\%CI: } 0.64-1.02) \\
\text { Gestational age } 25-28 \text { (highest HR): } \\
\text { HR }=1.39 \text { (95\%CI: } 1.01-1.75) \\
\text { Similar results when maternal } \\
\text { urinary arsenic concentration was } \\
\text { used in the model }\end{array}$ & $\rightarrow /(\uparrow)$ & 8 \\
\hline $\begin{array}{l}\text { Aschengrau et. } \\
\text { al., 1989, USA }\end{array}$ & Case-control study & $\begin{array}{c}\text { Total: } 1677 \\
\text { Case: } 286 \text { spontaneous } \\
\text { abortions } \\
\text { Control: } 1391 \\
\text { completed pregnancies }\end{array}$ & $\begin{array}{l}\text { None (undetectable) } \\
\text { Low: } 0.8-1.3 \mu \mathrm{g} / \mathrm{L} \\
\text { High: } 1.4-1.9 \mu \mathrm{g} / \mathrm{L}\end{array}$ & $\begin{array}{l}\text { Spontaneous } \\
\text { abortion } \\
(<28 \text { weeks })\end{array}$ & $\begin{array}{c}\text { Maternal age } \\
(<30 \text { years and }>30 \\
\text { years }) \\
\text { Educational level } \\
\text { History of prior } \\
\text { abortions }\end{array}$ & $\begin{array}{c}\text { Non-significant, positive } \\
\text { association between arsenic levels } \\
\text { and risk of spontaneous abortion. } \\
\text { All subjects adjusted: } \\
\text { Low: OR = } 1.1 \text { (95\%CI: } 0.6-1.8) \\
\text { High: OR = } 1.5 \text { (95\%CI: } 0.4-4.7 \text { ) }\end{array}$ & $(\uparrow)$ & 9 \\
\hline $\begin{array}{c}\text { Banu et. al., 2013, } \\
\text { Bangladesh }\end{array}$ & $\begin{array}{l}\text { Cohort study, } \\
\text { prospectively } \\
\text { collected } \\
\text { information on } \\
\text { exposure }\end{array}$ & $\begin{array}{l}\text { Total: } 421 \text { pregnant } \\
\text { women } \\
\text { Case: } 30 \text { spontaneous } \\
\text { abortions } \\
\text { Comparison: None }\end{array}$ & $\begin{array}{c}\text { Average for all participants: } \\
36.1 \mu \mathrm{g} / \mathrm{L} \\
(\mathrm{SD}=83.7 \text { and } \\
\text { range } \leq 1-880 \mu \mathrm{g} / \mathrm{L})\end{array}$ & $\begin{array}{l}\text { Spontaneous } \\
\text { abortion or } \\
\text { miscarriage (not } \\
\text { specified) }\end{array}$ & None & $\begin{array}{l}30 \text { pregnancies resulted in } \\
\text { spontaneous abortion or } \\
\text { miscarriage }(7.1 \%)\end{array}$ & $\begin{array}{c}\text { Not } \\
\text { applicable }\end{array}$ & 4 \\
\hline $\begin{array}{c}\text { Bloom et. al., } \\
\text { 2014, Romania }\end{array}$ & $\begin{array}{l}\text { Case-control } \\
\text { study }\end{array}$ & $\begin{array}{c}\text { Total: } 300 \\
\text { Case: } 150 \text { spontaneous } \\
\text { abortions } \\
\text { Control: } 150 \text { ongoing } \\
\text { pregnancies }\end{array}$ & $\begin{array}{l}\text { Case: } \\
\text { Average: } 4.06 \mu \mathrm{g} / \mathrm{L} \\
\text { Control: } \\
\text { Average: } 4.32 \mu \mathrm{g} / \mathrm{L}\end{array}$ & $\begin{array}{l}\text { Spontaneous } \\
\text { abortion } \\
(<21 \text { weeks }) .\end{array}$ & $\begin{array}{c}\text { Maternal age } \\
\text { Smoking during } \\
\text { pregnancy } \\
\text { Educational level } \\
\text { Prenatal vitamin use }\end{array}$ & $\begin{array}{c}\text { No increased risk of spontaneous } \\
\text { pregnancy loss in association with } \\
\text { continuous inorganic arsenic } \\
\text { exposure } \\
\text { Average inorganic arsenic levels: } \\
\text { OR }=0.98 \text { ( } 95 \% \text { CI: } 0.96-1.01)\end{array}$ & $\rightarrow$ & 8 \\
\hline
\end{tabular}


Table 1. Cont.

\begin{tabular}{|c|c|c|c|c|c|c|c|c|}
\hline $\begin{array}{l}\text { Author, Year, } \\
\text { Country }\end{array}$ & Study Design & $\begin{array}{l}\text { Study Population } \\
\text { (Size and Selection) }\end{array}$ & Exposure Assessment & Outcome & $\begin{array}{l}\text { Confounding } \\
\text { Control }\end{array}$ & Main Results ${ }^{1}$ & $\begin{array}{c}\text { Effect of } \\
\text { Arsenic } \\
\text { Exposure }^{2}\end{array}$ & $\begin{array}{c}\text { Total } \\
\text { NOS-Score }\end{array}$ \\
\hline $\begin{array}{l}\text { Mukherjee et. al., } \\
\text { 2005, India }\end{array}$ & $\begin{array}{l}\text { Cohort study, } \\
\text { retrospectively } \\
\text { collected } \\
\text { information on } \\
\text { exposure }\end{array}$ & $\begin{array}{c}\text { Total: } 24 \\
\text { Case: } 17 \text { (high arsenic } \\
\text { exposure) } \\
\text { Comparison: } 7 \text { (low } \\
\text { arsenic exposure) }\end{array}$ & $\begin{array}{c}\text { Case: } \\
\text { Group A: } 284-400 \mu \mathrm{g} / \mathrm{L} \\
\text { Group B: } 401-1474 \mu \mathrm{g} / \mathrm{L} \\
\\
\text { Comparison: } \\
\text { Group C: }<3 \mu \mathrm{g} / \mathrm{L}\end{array}$ & $\begin{array}{c}\text { Spontaneous } \\
\text { abortion (not } \\
\text { specified) }\end{array}$ & None & $\begin{array}{c}\text { The number of spontaneous } \\
\text { abortions increased with increasing } \\
\text { arsenic levels in drinking water } \\
\text { Group A: } 2 \text { spontaneous abortion } \\
\text { ( } 95 / 1000 \text { live births) } \\
\text { Group B: } 8 \text { spontaneous abortion } \\
\text { (182/1000 live births) } \\
\text { Group C: } 1 \text { spontaneous abortion } \\
\text { (55/1000 live births) }\end{array}$ & $\begin{array}{c}\text { Not } \\
\text { applicable }\end{array}$ & 2 \\
\hline $\begin{array}{c}\text { Rahman et. al., } \\
\text { 2007, } \\
\text { Bangladesh }\end{array}$ & $\begin{array}{l}\text { Cohort study, } \\
\text { prospectively } \\
\text { collected } \\
\text { information on } \\
\text { exposure }\end{array}$ & $\begin{array}{c}\text { Total: } 29,134 \text { pregnant } \\
\text { women }\end{array}$ & $\begin{array}{l}\text { 1st quintile (reference): } \\
\quad<10 \mu \mathrm{g} / \mathrm{L} \\
\text { 2nd quintile: } 10-166 \mu \mathrm{g} / \mathrm{L} \\
\text { 3rd quintile: } 167-276 \mu \mathrm{g} / \mathrm{L} \\
\text { 4th quintile: } 277-408 \mu \mathrm{g} / \mathrm{L} \\
\text { 5th quintile: } \geq 409 \mu \mathrm{g} / \mathrm{L}\end{array}$ & $\begin{array}{c}\text { Fetal loss } \\
\text { (early }<28 \text { weeks, } \\
\text { late }>28 \text { weeks) }\end{array}$ & $\begin{array}{c}\text { Maternal age } \\
\text { Parity } \\
\text { Educational level } \\
\text { Socioeconomic status }\end{array}$ & $\begin{array}{c}\text { A tendency of increased risk of fetal } \\
\text { loss for higher quintiles of water } \\
\text { arsenic concentrations, although } \\
\text { only significant for the } 4 \text { th quintile } \\
\text { (pooled results): } \\
\text { 4th quintile: } \mathrm{RR}=1.14 \\
\text { (95\%CI: } 1.01-1.30) \\
\text { If exposure was dichotomized } \\
\text { below and above } 50 \mu \mathrm{g} / \mathrm{L}: \\
\mathrm{RR}=1.14 \text { (CI95\%: } 1.04-1.25)\end{array}$ & $(\uparrow)$ & 6 \\
\hline $\begin{array}{l}\text { Susko et. al., } \\
\text { 2017, Romania }\end{array}$ & $\begin{array}{l}\text { Cohort study, } \\
\text { retrospectively } \\
\text { collected } \\
\text { information on } \\
\text { exposure }\end{array}$ & $\begin{array}{l}\text { Total: } 287 \text { previously } \\
\text { pregnant women } \\
\text { Case: } 94 \text { planned } \\
\text { pregnancies } \\
\text { Comparison: } 193 \\
\text { unplanned } \\
\text { pregnancies }\end{array}$ & $\begin{array}{c}\text { Planned: } \\
\text { Average: } 4.63 \mu \mathrm{g} / \mathrm{L} \\
\text { Peak: } 5.55 \mu \mathrm{g} / \mathrm{L} \\
\text { Estimated daily: } 7.29 \mu \mathrm{g} / \mathrm{L} \\
\text { Unplanned: } \\
\text { Average: } 4.11 \mu \mathrm{g} / \mathrm{L} \\
\text { Peak: } 4.59 \mu \mathrm{g} / \mathrm{L} \\
\text { Estimated daily: } 5.75 \mu \mathrm{g} / \mathrm{L}\end{array}$ & $\begin{array}{l}\text { Time to } \\
\text { pregnancy }\end{array}$ & $\begin{array}{c}\text { Maternal age } \\
\text { Cigarette smoking } \\
\text { Educational level }\end{array}$ & $\begin{array}{c}\text { No main effects for low-level } \\
\text { drinking water arsenic on women's } \\
\text { fecundity } \\
\text { For women with a longer time to } \\
\text { pregnancy, modestly lower } \\
\text { pregnancy probabilities were } \\
\text { observed with higher arsenic } \\
\text { exposure }\end{array}$ & $\rightarrow /(\uparrow)$ & 6 \\
\hline
\end{tabular}

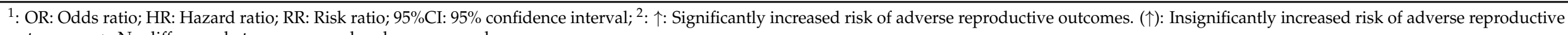
outcomes. $\rightarrow$ : No difference between exposed and non-exposed groups. 


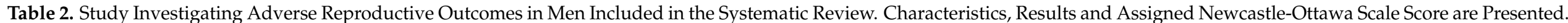

\begin{tabular}{|c|c|c|c|c|c|c|c|c|}
\hline $\begin{array}{c}\text { Author, } \\
\text { Year, } \\
\text { Country }\end{array}$ & $\begin{array}{l}\text { Study } \\
\text { Design }\end{array}$ & $\begin{array}{c}\text { Study Population (Size and } \\
\text { Selection) }\end{array}$ & $\begin{array}{l}\text { Exposure } \\
\text { Assessment }\end{array}$ & Outcome & $\begin{array}{c}\text { Confounding Control } \\
\text { (Smoking Status and } \\
\text { Other (Alcohol } \\
\text { Consumption, BMI, Age)) }\end{array}$ & Main Results & $\begin{array}{c}\text { Effect of } \\
\text { Arsenic } \\
\text { Exposure }{ }^{1}\end{array}$ & $\begin{array}{l}\text { Total NOS- } \\
\text { Score }\end{array}$ \\
\hline $\begin{array}{c}\text { Sengupta, } \\
2013, \\
\text { India }\end{array}$ & $\begin{array}{l}\text { Case-control } \\
\text { study }\end{array}$ & $\begin{array}{c}\text { Total: } 100 \text { men } \\
\text { Cases: } 68(\text { sperm } \\
\text { Control: } 32(\text { sperm } \\
\left.\text { concentration }<20 \times 10^{6} / \mathrm{mL}\right) \\
\left.\text { concentration }>20 \times 10^{6} / \mathrm{mL}\right)\end{array}$ & $\begin{array}{c}\text { Mean drinking water } \\
\text { arsenic } \\
\text { concentrations: } \\
\text { Cases: } \\
\text { Azoospermia: } \\
2585 \mu \mathrm{g} / \mathrm{L} \\
\text { Oligospermia: } \\
2042 \mu \mathrm{g} / \mathrm{L} \\
\\
\text { Control: } \\
\text { Normozoospermia: } \\
149 \mu \mathrm{g} / \mathrm{L}\end{array}$ & $\begin{array}{l}\text { Sperm concentration: } \\
<20 \times 10^{6} / \mathrm{mL} \\
\text { (azoospermia and } \\
\text { oligospermia) } \\
\\
>20 \times 10^{6} / \mathrm{mL} \\
\text { (normozoospermia) }\end{array}$ & $\begin{array}{c}\text { Smoking } \\
\text { Alcohol } \\
\text { Tobacco chewing } \\
\text { Dietary habits }\end{array}$ & $\begin{array}{c}\text { Mean drinking water arsenic and } \\
\text { mean seminal arsenic content } \\
\text { were both significantly higher } \\
\text { amongst cases compared to } \\
\text { controls }(p<0.05) \text {. } \\
\\
\text { Mean drinking water arsenic } \\
\text { levels were positively correlated } \\
(\mathrm{r}=0.867) \text { with mean seminal } \\
\text { plasma arsenic levels. } \\
\text { Arsenic content in drinking water } \\
\text { and total sperm count was } \\
\text { inversely related }(\mathrm{r}=-0.91)\end{array}$ & $\uparrow$ & 6 \\
\hline
\end{tabular}

${ }^{1}: \uparrow:$ Significantly increased risk of adverse reproductive outcomes. 


\subsection{Men}

High-Level Arsenic Exposure (Above $10 \mu \mathrm{g} / \mathrm{L}$ )

Only one study, Sengupta et al. [19], was deemed eligible for inclusion in this systematic review, by reporting on arsenic levels in drinking water and semen quality parameters. In this case-control study of 100 men, a positive correlation between arsenic levels in drinking water and seminal plasma was found, and mean drinking water arsenic and mean seminal arsenic content were both significantly higher among cases (men with oligozoospermia or azoospermia) compared to controls (men with normozoospermia). Furthermore, the arsenic content in drinking water and total sperm count was inversely related. Additionally, a higher fraction of abnormal sperm morphology, and thus motility, was found in cases compared to controls.

\section{Discussion}

This systematic review identified one study reporting an association between arsenic exposure from drinking water and an adverse effect on semen quality characteristics in men and an accumulation of arsenic in seminal plasma. These findings are, however, at high arsenic levels ( $>1000 \mu \mathrm{g} / \mathrm{L})$, and the study was not classified as a high-quality study. No clear significant association between arsenic exposure and the risk of spontaneous abortion was found, although there was a suggestion of a timing and dose-dependent association throughout pregnancy. One study reported modestly lowered pregnancy probabilities for women with extended TTP with higher arsenic exposure, but no overall association was found between exposure to low-level arsenic in drinking water and women's fecundity when measured as TTP.

Of the eight included studies, the comparison was challenged by the heterogeneous outcome definitions. Furthermore, only three were designated a NOS-score equal to or above 7 , and all investigated outcomes were in women $[30,31,33]$. Assessing these separately did not change the overall conclusion of this systematic review.

\subsection{Strengths and Limitations}

This review is the first to systematically review published studies investigating the influence of arsenic exposure from drinking water on reproductive outcomes in both females and males. The arsenic exposure assessment through drinking water has higher precision, compared to urine samples, in areas where water is estimated to be the primary exposure route, as urine concentrations may vary with hydration status.

However, the study has some possible limitations. Firstly, there might be incomplete data retrieval due to publication bias. By manual review of reference lists of included or relevant literature, this was sought to be solved; however, non-published data were not traced. Secondly, regardless of the comprehensive literature search, only a few studies were deemed eligible for inclusion, thereby restricting our conclusion to the findings of eight studies. Some relevant publications may have been left out (see Supplementary Materials). Lastly, by using the NOS to quality assess included studies; we might categorise some studies as "low-quality" simply because the authors did not provide detailed information in the publication.

\subsection{Spontaneous Abortion}

An issue when interpreting the results from the studies investigating spontaneous abortion as an endpoint is the lack of consensus on its definition. In Denmark, the cutoff for spontaneous abortion is set at 22 full weeks of gestation [36]. Another given by UpToDate is set at 20 weeks of gestation [37]. All six included studies applied different definitions or did not specify the cut-off of gestational age, which limits their comparability. Studies defining an earlier cut-off will naturally have a lower incidence due to the shorter period-and vice versa-leading to over- and underestimations of events occurring, and thus affecting the assessed impact of arsenic. 
Another aspect to consider is the unrecognised early spontaneous abortions that may give rise to survival bias. This under-reporting of the outcome lowers the incidence and possibly also presents a biased result [38].

Several studies did not qualify for inclusion in this review. Most research reporting pregnancy outcomes were studies of cross-sectional or ecological design [39-47], precluding temporality [48]. In a meta-analysis conducted in 2015 [12], authors found a positive association between high-level arsenic exposure and spontaneous abortion whereas their findings on low-to-moderate arsenic levels were inconclusive. The interpretation of associations should, however, be done with care, as most of the included literature has methodological problems. Indeed, in this systematic review, where only case-control and cohort studies were included, the same statistically significant association was not found.

An additional few cohort studies were found reporting spontaneous abortion, but these studies assessed arsenic exposure from urinary samples and were thus not included $[49,50]$. One study found a non-significant elevation in odds ratio (OR) for spontaneous abortion, but no dose-response relationship, in a population with high arsenic exposure [50]. Similarly, another study showed a non-significant increase in OR for spontaneous abortion with increased arsenic levels [49].

As most studies in this field are carried out in developing countries, it is important to reflect on the external validity of these reports.

\subsection{Female Infertility and Fecundity}

Apart from the included study reporting female fecundity or infertility [29], only one other study was found to investigate this same outcome in humans [51]. Arsenic exposure was assessed from blood samples and no association of arsenic exposure (primarily through non-toxic arsenical species from seafood consumption) and extended TTP was found.

No studies reporting on associations between arsenic exposure and any form of assisted reproductive technology were found, and only a single study reporting on menstrual disturbances was traced, but this was left out due to language restriction [52].

\subsection{Male Infertility and Semen Quality Parameters}

Only one male study met the inclusion criteria, but had several methodological limitations, and was awarded a NOS-score of 6 . In general, both manuscript setup, and study population and data presentation were complicated, and interpretation of the results therefore challenging.

Another aspect to consider is that the arsenic exposure levels were much higher for the participants in Sengupta et al. compared to the participants in other included studies. Indeed, the control group had arsenic levels ranging higher than the case groups in most other included studies (see Tables 1 and 2). By inspection of the graphics in Sengupta et al., it appears to be high drinking water arsenic concentrations above $1000 \mu \mathrm{g} / \mathrm{L}$ that were associated with oligo- and azoospermia. These values are beyond the average arsenic content in most groundwater sources [53]. This should be considered when interpreting the validity of the stated conclusions.

Several studies investigating arsenic exposure were identified but did not qualify for inclusion, as was the case for pregnancy outcomes. Most research reporting on male infertility was of cross-sectional or ecologic design, having the same methodological challenges as previously described. Arsenic exposure assessment was performed by analysing various metabolites in either urine $[16,20,21,54,55]$, blood [56-58] or seminal plasma [57-61], and outcome specification varies greatly making comparisons complex. Findings are generally conflicting, and not consistent.

An additional three case-control studies were identified, but none of them measured arsenic exposure in drinking water. Wang et al. [18] investigated the risk of unexplained male infertility (UMI) with exposure to arsenic in $162 \mathrm{men}$. They assessed arsenic exposure with urinary arsenic measurement and found that the primary methylation capacity of inorganic arsenic was significantly associated with an increased risk of UMI. Several 
arsenical metabolites were investigated, and contra-intuitively, only the species known to be the least toxic $\left(\mathrm{iAs}^{\mathrm{V}}\right)$ was significantly associated with UMI. Shen et al. [62] similarly demonstrated significantly increased adjusted odds ratio for idiopathic male infertility with increasing levels of iAs ${ }^{\mathrm{v}}$, and likewise did not demonstrate increased odds ratio for any other arsenical metabolites. Meeker et al. [17] assessed multiple metals in whole venous blood from 219 men and found suggestive evidence for non-monotonic inverse associations between arsenic and semen quality parameters when arsenic was considered individually.

When investigating male infertility, one must bear in mind that lower semen quality does not necessarily mean increased male infertility, as it is difficult to draw conclusions based on semen characteristics alone. Furthermore, seminal plasma mostly arises from non-gonadal sources (e.g., seminal vesicles and prostate) [63], and high arsenic levels in seminal plasma, can thus not readily be interpreted as a result of gonadal bioaccumulation.

\subsection{Assessment of Arsenic Exposure}

Comparing results from studies investigating the individual arsenic exposure may be difficult due to the different methods used to address exposure (water, urine, blood or seminal plasma). There is no consensus on how to transform and compare the results.

Interpretation of iAs from urine or blood is complicated by the incomplete metabolization upon ingestion. These species have significantly varying toxicity [18], thus, conclusions should be drawn with care, as it might introduce large uncertainty in arsenic exposure.

The available studies assessing arsenic exposure from drinking water are challenged by the lack of certainty in determining exposure on an individual level [31]. However, by using drinking water in the assessment of arsenic exposure, hydration status and metabolism rate are not issues that need to be accounted for (in contrast to using urine or blood). Thus, the arsenic exposure assessment through drinking water will have higher precision than by using urine in areas where water is estimated to be the primary exposure route, which is a strength of this systematic review. In areas with industrial mining or areas with a high intake of rice and shellfish, these exposure routes need to be considered and assessed equally when estimating arsenic exposure.

Furthermore, using the information on drinking water arsenic from the nationwide quality control measurements would enable observational studies with large study populations and greater exposure contrast, and the possibility to investigate associations with rare reproductive outcomes. In addition, it is an ethically justifiable study design, when investigating a substance with multiple known adverse health consequences. Studies using datasets with time-specific drinking water assessment by certified monitoring databases, linked to universal health registries, as well as the availability of covariate- and confounder information could strengthen the evidence in this field.

Several factors complicate the estimation of arsenic's effect using any source making the evaluation of arsenic toxicity extremely complex. One factor is the varying interindividual arsenic sensitivity and metabolism capacity [64]. Another is in utero and early life arsenic exposure which is associated with the increased risk of adverse effects in later life [30,65]. Bioaccumulation of arsenic in reproductive tissues, e.g., as described in human gonadal tissue [19], may also have significance for toxicity over time [66]. Additionally, some authors also report on metabolism changes during pregnancy; these results are, however, conflicting $[67,68]$. Co-contaminants such as cadmium, lead, or fluoride may influence the bioavailability and metabolism of arsenic [65], and other covariates such as smoking have been suggested to potentiate otherwise benign exposure of arsenic [69].

\section{Conclusions}

Overall, no strong evidence was found in this systematic review to support an association between arsenic exposure in drinking water and increased risk of spontaneous abortion regardless of exposure level. A tendency toward lowered pregnancy probabilities for women with extended TTP, with higher arsenic exposure was found, but there is not 
sufficient evidence to support the overall hypothesis that exposure to low-level arsenic in drinking water adversely impacts women's fecundity when measured as TTP.

The almost non-existing literature on arsenic exposure from drinking water and male infertility and semen quality parameters stress the need for further studies. The only study qualified for inclusion in this systematic review found that mean drinking water arsenic and mean seminal arsenic content were both significantly higher among cases compared to controls, indicating an accumulation in seminal plasma. Additionally, an association between increasing arsenic exposure and decreasing semen quality characteristics was indicated. These findings are however at high arsenic levels $(>1000 \mu \mathrm{g} / \mathrm{L})$, and the study was not classified as a high-quality study.

No studies reported on any form of assisted reproductive technology, and only a single study reporting on menstrual disturbances was found but left out due to language restriction.

The present evidence is very sparse and outcome assessments vary greatly. As the reports from the existing evidence, mainly from cross-sectional or ecologic studies, are conflicting, large epidemiological studies including data on early fetal loss and individual time-specific exposure levels with large exposure contrast are needed.

Supplementary Materials: The following are available online at https:/ /www.mdpi.com/article/ 10.3390/w13141885/s1. Text S1: Full search strategy (PubMed/Medline). Text S2: Data extraction form. Text S3: Elaborated reasons for exclusions. Text S4: Newcastle-Ottawa Scale; Table S4: Scores; Text S4.1: Explanatory form. References, Supplementary Materials.

Author Contributions: Conceptualization, I.M.B., N.H.E., U.B.K.; Methodology, I.M.B., N.H.E., H.S.C. and U.B.K.; Validation, I.M.B., N.H.E.; Formal Analysis, I.M.B., N.H.E.; Investigation, I.M.B., N.H.E.; Data Curation, I.M.B., N.H.E.; Writing—Original Draft Preparation, I.M.B.; Writing-Review \& Editing, I.M.B., N.H.E., H.S.C., J.L., J.S., C.H.R.-H., B.B. and U.B.K.; Visualization, I.M.B.; Supervision, N.H.E., U.B.K.; Project Administration, I.M.B., N.H.E., U.B.K. All authors have read and agreed to the published version of the manuscript.

Funding: There have been no grants, fellowships or other funding supporting the writing of this paper.

Informed Consent Statement: Not applicable.

Data Availability Statement: No new data were created or analyzed in this study. Data sharing is not applicable to this article.

Conflicts of Interest: B.B. reports personal fees from Merck (Lecture for fertility staff in offspring health following ART), outside the submitted work. This had no role in the design of the study; in the collection, analyses, or interpretation of data; in the writing of the manuscript, or in the decision to publish the results. The remaining authors have nothing to disclose; separate ICMJE forms available.

\section{References}

1. Juul, S.; Karmaus, W.; Olsen, J. Regional differences in waiting time to pregnancy: Pregnancy-based surveys from Denmark, France, Germany, Italy and Sweden. The European Infertility and Subfecundity Study Group. Hum. Reprod. 1999, 14, 1250-1254. [CrossRef] [PubMed]

2. Ombelet, W.; Cooke, I.; Dyer, S.; Serour, G.; Devroey, P. Infertility and the provision of infertility medical services in developing countries. Hum. Reprod. Updat. 2008, 14, 605-621. [CrossRef] [PubMed]

3. Weselak, M.; Arbuckle, T.E.; Walker, M.C.; Krewski, D. The influence of the environment and other exogenous agents on spontaneous abortion risk. J. Toxicol. Environ. Health Part B 2008, 11, 221-241. [CrossRef] [PubMed]

4. IARC International Agency for Research on Cancer. Arsenic, Metals, Fibres and Dusts. A Review of Human Carcinogens. 2012. Available online: https:/ / monographs.iarc.fr/wp-content/uploads/2018/06/mono100C.pdf (accessed on 15 November 2019).

5. Smedley, P.; Kinniburgh, D. A review of the source, behaviour and distribution of arsenic in natural waters. Appl. Geochem. 2002, 17, 517-568. [CrossRef]

6. World Health Organization (WHO). Guidelines for Drinking-Water Quality, Fourth Edition, Geneva 2011. Available online: https://www.who.int/water_sanitation_health/dwq/chemicals/arsenic.pdf (accessed on 15 November 2019).

7. Haque, R.; Mazumder, D.N.; Samanta, S.; Ghosh, N.; Kalman, D.; Smith, M.M.; Mitra, S.; Santra, A.; Lahiri, S.; Das, S.; et al. Arsenic in drinking water and skin lesions: Dose-response data from West Bengal, India. Epidemiology 2003, 14, 174-182. [CrossRef]

8. Kuo, C.C.; Moon, K.A.; Wang, S.L.; Silbergeld, E.; Navas-Acien, A. The Association of Arsenic Metabolism with Cancer, Cardiovascular Disease, and Diabetes: A Systematic Review of the Epidemiological Evidence. Environ. Health Perspect. 2017, 125, 087001. [CrossRef] 
9. Moon, K.A.; Guallar, E.; Umans, J.G.; Devereux, R.B.; Best, L.G.; Francesconi, K.A.; Goessler, W.; Pollak, J.; Silbergeld, E.K.; Howard, B.V.; et al. Association between exposure to low to moderate arsenic levels and incident cardiovascular disease. A prospective cohort study. Ann. Intern. Med. 2013, 159, 649-659.

10. Hamadani, J.D.; Tofail, F.; Nermell, B.; Gardner, R.; Shiraji, S.; Bottai, M.; Arifeen, S.E.; Huda, S.N.; Vahter, M. Critical windows of exposure for arsenic-associated impairment of cognitive function in pre-school girls and boys: A population-based cohort study. Int. J. Epidemiol. 2011, 40, 1593-1604. [CrossRef]

11. Vahter, M. Effects of arsenic on maternal and fetal health. Annu. Rev. Nutr. 2009, 29, 381-399. [CrossRef]

12. Quansah, R.; Armah, F.A.; Essumang, D.K.; Luginaah, I.; Clarke, E.; Marfoh, K.; C obbina, S.J.; Nketiah-Amponsah, E.; Namujju, P.B.; Obiri, S.; et al. Association of arsenic with adverse pregnancy outcomes/infant mortality: A systematic review and meta-analysis. Environ. Health Perspect. 2015, 123, 412-421. [CrossRef]

13. He, W.; Greenwell, R.J.; Brooks, D.M.; Calderon-Garciduenas, L.; Beall, H.D.; Coffin, J.D. Arsenic exposure in pregnant mice disrupts placental vasculogenesis and causes spontaneous abortion. Toxicol. Sci. 2007, 99, 244-253. [CrossRef] [PubMed]

14. Navarro, P.A.; Liu, L.; Keefe, D.L. In vivo effects of arsenite on meiosis, preimplantation development, and apoptosis in the mouse. Biol. Reprod. 2004, 70, 980-985. [CrossRef] [PubMed]

15. Hsieh, F.I.; Hwang, T.S.; Hsieh, Y.C.; Lo, H.C.; Su, C.T.; Hsu, H.S.; Chiou, H.Y.; Chen, C.J. Risk of erectile dysfunction induced by arsenic exposure through well water consumption in Taiwan. Environ. Health Perspect. 2008, 116, 532-536. [CrossRef] [PubMed]

16. Xu, W.; Bao, H.; Liu, F.; Liu, L.; Zhu, Y.G.; She, J.; Dong, S.; Cai, M.; Li, L.; Li, C.; et al. Environmental exposure to arsenic may reduce human semen quality: Associations derived from a Chinese cross-sectional study. Environ. Health 2012, 11, 46. [CrossRef] [PubMed]

17. Meeker, J.D.; Rossano, M.G.; Protas, B.; Diamond, M.P.; Puscheck, E.; Daly, D.; Paneth, N.; Wirth, J.J. Cadmium, lead, and other metals in relation to semen quality: Human evidence for molybdenum as a male reproductive toxicant. Environ. Health Perspect. 2008, 116, 1473-1479. [CrossRef]

18. Wang, X.; Zhang, J.; Xu, W.; Huang, Q.; Liu, L.; Tian, M.; Xia, Y.; Zhang, W.; Shen, H. Low-level environmental arsenic exposure correlates with unexplained male infertility risk. Sci. Total. Environ. 2016, 571, 307-313. [CrossRef]

19. Sengupta, M.; Deb, I.; Sharma, G.D.; Kar, K.K. Human sperm and other seminal constituents in male infertile patients from arsenic and cadmium rich areas of Southern Assam. Syst. Biol. Reprod. Med. 2013, 59, 199-209. [CrossRef]

20. Oguri, T.; Yoshinaga, J.; Toshima, H.; Mizumoto, Y.; Hatakeyama, S.; Tokuoka, S. Urinary inorganic arsenic concentrations and semen quality of male partners of subfertile couples in Tokyo. J. Environ. Sci. Health Part A 2016, 51, 463-466. [CrossRef]

21. Jeng, H.A.; Huang, Y.L.; Pan, C.H.; Diawara, N. Role of low exposure to metals as male reproductive toxicants. Int. J. Environ. Health Res. 2014, 25, 405-417. [CrossRef]

22. Pant, N.; Murthy, R.C.; Srivastava, S.P. Male reproductive toxicity of sodium arsenite in mice. Hum. Exp. Toxicol. 2004, 23, 399-403. [CrossRef]

23. Reddy, P.S.; Rani, G.P.; Sainath, S.B.; Meena, R.; Supriya, C. Protective effects of N-acetylcysteine against arsenic-induced oxidative stress and reprotoxicity in male mice. J. Trace Elem. Med. Biol. 2011, 25, 247-253. [CrossRef] [PubMed]

24. Sanghamitra, S.; Hazra, J.; Upadhyay, S.N.; Singh, R.K.; Amal, R.C. Arsenic induced toxicity on testicular tissue of mice. Indian J. Physiol. Pharmacol. 2008, 52, 84-90.

25. Huang, Q.; Luo, L.; Alamdar, A.; Zhang, J.; Liu, L.; Tian, M.; Eqani, S.A.; Shen, H. Integrated proteomics and metabolomics analysis of rat testis: Mechanism of arsenic-induced male reproductive toxicity. Sci. Rep. 2016, 6, 32518. [CrossRef] [PubMed]

26. Liberati, A.; Altman, D.G.; Tetzlaff, J.; Mulrow, C.; Gotzsche, P.C.; Ioannidis, J.P.; Clarke, M.; Devereaux, P.J.; Kleijnen, J.; Moher, D. The PRISMA statement for reporting systematic reviews and meta-analyses of studies that evaluate health care interventions: Explanation and elaboration. J. Clin. Epidemiol. 2009, 62, e1-e34. [CrossRef]

27. National Institute for Health Research. PROSPERO Protocol. Available online: https://www.crd.york.ac.uk/prospero/ (accessed on 15 November 2019).

28. Wells, G.S.B.; O'Connell, D.; Peterson, J.; Welch, V.; Losos, M.; Tugwell, P. The Newcastle-Ottawa Scale (NOS) for Assessing the Quality of Nonrandomised Studies in Meta-Analyses. Available online: http:/ / www.ohri.ca/programs/clinical_epidemiology/ oxford.asp (accessed on 15 November 2019).

29. Susko, M.L.; Bloom, M.S.; Neamtiu, I.A.; Appleton, A.A.; Surdu, S.; Pop, C.; Fitzgerald, E.F.; Anastasiu, D.; Gurzau, E.S. Low-level arsenic exposure via drinking water consumption and female fecundity-A preliminary investigation. Environ. Res. 2017, 154, 120-125. [CrossRef] [PubMed]

30. Ahmed, S.M.; Noble, B.N.; Joya, S.A.; Ibn Hasan, M.O.S.; Lin, P.I.; Rahman, M.L.; Mostofa, G.; Quamruzzaman, Q.; Rahman, M.; Christiani, D.C.; et al. A Prospective Cohort Study Examining the Associations of Maternal Arsenic Exposure With Fetal Loss and Neonatal Mortality. Am. J. Epidemiol. 2018, 188, 347-354. [CrossRef]

31. Aschengrau, A.; Zierler, S.; Cohen, A. Quality of community drinking water and the occurrence of spontaneous abortion. Arch Environ. Health Int. J. 1989, 44, 283-290. [CrossRef]

32. Banu, S.A.; Kile, M.L.; Christiani, D.C.; Qumruzzaman, Q. Study of prenatal arsenic exposure and reproductive health outcome in Bangladesh. Bangladesh J. Obstet. Gynaecol. 2016, 28, 76-81. [CrossRef]

33. Bloom, M.S.; Neamtiu, I.A.; Surdu, S.; Pop, C.; Lupsa, I.R.; Anastasium, D.; Fitzgerald, E.F.; Gurzau, E.S. Consumption of low-moderate level arsenic contaminated water does not increase spontaneous pregnancy loss: A case control study. Environ. Health 2014, 13, 1-10. [CrossRef] 
34. Mukherjee, S.C.; Saha, K.C.; Pati, S.; Dutta, R.N.; Rahman, M.M.; Sengupta, M.K.; Ahamed, S.; Lodh, D.; Das, B.; Hossain, M.; et al. Murshidabad-One of the nine groundwater arsenic-affected districts of West Bengal, India. Part II: Dermatological, neurological, and obstetric findings. Clin. Toxicol. 2005, 43, 835-848. [CrossRef]

35. Rahman, A.; Vahter, M.; Ekström, E.C.; Rahman, M.; Golam Mustafa, A.H.M.; Wahed, M.A.; Yunus, M.; Persson, L.Å. Association of arsenic exposure during pregnancy with fetal loss and infant death: A cohort study in Bangladesh. Am. J. Epidemiol. 2007, 165, 1389-1396. [CrossRef]

36. Laegehaandbogen. Spontan Abort 2019. Available online: https://www.sundhed.dk/sundhedsfaglig/laegehaandbogen/ obstetrik/tilstande-og-sygdomme/aborter/spontan-abort/ (accessed on 31 October 2019).

37. Prager, S.M.; Micks, E.; Dalton, V.K. Pregnancy Loss (Miscarriage): Risk Factors, Etiology, Clinical Manifestations, and Diagnostic Evaluation. UpToDate. 2019. Available online: https:/ / www.uptodate.com/contents/pregnancy-loss-miscarriage-risk-factorsetiology-clinical-manifestations-and-diagnostic-evaluation (accessed on 24 November 2019).

38. Liew, Z.; Olsen, J.; Cui, X.; Ritz, B.; Arah, O.A. Bias from conditioning on live birth in pregnancy cohorts: An illustration based on neurodevelopment in children after prenatal exposure to organic pollutants. Int. J. Epidemiol. 2015, 44, 345-354. [CrossRef] [PubMed]

39. Borzsonyi, M.; Bereczky, A.; Rudnai, P.; Csanady, M.; Horvath, A. Epidemiological studies on human subjects exposed to arsenic in drinking water in Southeast Hungary. Arch. Toxicol. 1992, 66, 77-78. [CrossRef] [PubMed]

40. Guo, X.; Fujino, Y.; Chai, J.; Wu, K.; Xia, Y.; Li, Y.; Lv, J.; Sun, Z.; Yoshimura, T. The prevalence of subjective symptoms after exposure to arsenic in drinking water in Inner Mongolia, China. J. Epidemiol. 2003, 13, 211-215. [CrossRef] [PubMed]

41. Ahmad, S.A.; Salim Ullah Sayed, M.H.; Barua, S.; Haque Khan, M.; Faruquee, M.H.; Jalil, A.; Abdul Hadi, S.; Kabir Talukder, H. Arsenic in drinking water and pregnancy outcomes. Environ. Health Perspect. 2001, 109, 629. [CrossRef] [PubMed]

42. Ahamed, S.; Sengupta, M.K.; Mukherjee, S.C.; Pati, S.; Mukherjee, A.; Rahman, M.M.; Hossain, M.A.; Das, B.; Nayak, B.; Pal, A.; et al. An eight-year study report on arsenic contamination in groundwater and health effects in Eruani Village, Bangladesh and an approach for its mitigation. J. Health Popul. Nutr. 2006, 24, 129-141. [PubMed]

43. Milton, A.H.; Smith, W.; Rahman, B.; Hasan, Z.; Kulsum, U.; Dear, K.; Rakibuddin, M.; Ali, A. Chronic arsenic exposure and adverse pregnancy outcomes in Bangladesh. Epidemiology 2005, 16, 82-86. [CrossRef]

44. Chakraborti, D.; Rahman, M.M.; Ahamed, S.; Dutta, R.N.; Pati, S.; Mukherjee, S.C. Arsenic groundwater contamination and its health effects in Patna district (capital of Bihar) in the middle Ganga plain, India. Chemosphere 2016, 152, 520-529. [CrossRef]

45. Chakraborti, D.; Rahman, M.M.; Das, B.; Chatterjee, A.; Das, D.; Nayak, B.; Pal, A.; Chowdhury, U.K.; Ahmed, S.; Biswas, B.K.; et al. Groundwater arsenic contamination and its health effects in India. Hydrogeol. J. 2017, 25, 1165-1181. [CrossRef]

46. Von Ehrenstein, O.S.; Guha Mazumder, D.N.; Hira-Smith, M.; Ghosh, N.; Yuan, Y.; Windham, G.; Ghosh, A.; Haque, R.; Lahiri, S.; Kalman, D.; et al. Pregnancy outcomes, infant mortality, and arsenic in drinking water in West Bengal, India. Am. J. Epidemiol. 2006, 163, 662-669. [CrossRef]

47. Sen, J.; Chaudhuri, A.B.D. Arsenic exposure through drinking water and its effect on pregnancy outcome in Bengali women. Arch. Ind. Hyg. Toxicol. 2008, 59, 271-275. [CrossRef]

48. Carlson, M.D.; Morrison, R.S. Study design, precision, and validity in observational studies. J. Palliat. Med. 2009, 12, 77-82. [CrossRef]

49. Shih, Y.H.; Islam, T.; Hore, S.K.; Sarwar, G.; Shahriar, M.H.; Yunus, M.; Graziano, J.H.; Harjes, J.; Baron, J.A.; Parvez, F.; et al. Associations between prenatal arsenic exposure with adverse pregnancy outcome and child mortality. Environ. Res. 2017, 158, 456-461. [CrossRef] [PubMed]

50. Rahman, A.; Persson, L.A.; Nermell, B.; El Arifeen, S.; Ekström, E.C.; Smith, A.H.; Vahter, M. Exposure and risk of spontaneous abortion, stillbirth, and infant mortality. Epidemiology 2010, 21, 797-804. [CrossRef] [PubMed]

51. Bloom, M.S.; Louis, G.M.; Sundaram, R.; Kostyniak, P.J.; Jain, J. Associations between blood metals and fecundity among women residing in New York State. Reprod. Toxicol. 2011, 31, 158-163. [CrossRef]

52. Yang, W.H.; Guo, Z.W.; Han, X.H.; Xia, Y.J.; Wu, K.G.; Li, Y.H. Influence of arsenic exposure on menstruation. Chin. J. Endem. 2013, 32, 27-29.

53. Mains, M. Arsenic in Danish Groundwater and Drinking Water with Focus on Human Exposure. Master's Thesis, Institute of Geoscience, Aarhus University, Aarhus, Denmark, 2018.

54. He, Y.; Zou, L.; Luo, W.; Yi, Z.; Yang, P.; Yu, S.; Liu, N.; Ji, J.; Guo, Y.; Liu, P.; et al. Heavy metal exposure, oxidative stress and semen quality: Exploring associations and mediation effects in reproductive-aged men. Chemosphere 2020, 244, 125498. [CrossRef] [PubMed]

55. Zeng, Q.; Feng, W.; Zhou, B.; Wang, Y.X.; He, X.S.; Yang, P.; You, L.; Yue, J.; Li, Y.F.; Lu, W.Q. Urinary metal concentrations in relation to semen quality: A cross-sectional study in China. Environ. Sci. Technol. 2015, 49, 5052-5059. [CrossRef] [PubMed]

56. Huang, Q.; Liu, L.; Wu, Y.; Wang, X.; Luo, L.; Nan, B.; Zhang, J.; Tian, M.; Shen, H. Seminal plasma metabolites mediate the associations of multiple environmental pollutants with semen quality in Chinese men. Environ. Int. 2019, 132, 105066. [CrossRef]

57. Bergamo, P.; Volpe, M.G.; Lorenzetti, S.; Mantovani, A.; Notari, T.; Cocca, E.; Cerullo, S.; Di Stasio, M.; Cerino, P.; Montano, L. Human semen as an early, sensitive biomarker of highly polluted living environment in healthy men: A pilot biomonitoring study on trace elements in blood and semen and their relationship with sperm quality and RedOx status. Reprod. Toxicol. 2016, 66, 1-9. [CrossRef] 
58. Sukhn, C.; Awwad, J.; Ghantous, A.; Zaatari, G. Associations of semen quality with non-essential heavy metals in blood and seminal fluid: Data from the Environment and Male Infertility (EMI) study in Lebanon. J. Assist. Reprod. Genet. 2018, 35, 1691-1701. [CrossRef]

59. Wang, Y.X.; Wang, P.; Feng, W.; Liu, C.; Yang, P.; Chen, Y.J.; Sun, L.; Sun, Y.; Yue, J.; Gu, L.J.; et al. Relationships between seminal plasma metals/metalloids and semen quality, sperm apoptosis and DNA integrity. Environ. Pollut. 2017, 224, 224-234. [CrossRef]

60. Liu, P.; Yuan, G.; Zhou, Q.; Liu, Y.; He, X.; Zhang, H.; Guo, Y.; Wen, Y.; Huang, S.; Ke, Y.; et al. The association between metal exposure and semen quality in Chinese males: The mediating effect of androgens. Environ. Pollut. 2020, 264, 113975. [CrossRef] [PubMed]

61. Li, P.; Zhong, Y.; Jiang, X.; Wang, C.; Zuo, Z.; Sha, A. Seminal plasma metals concentration with respect to semen quality. Biol. Trace Elem. Res. 2012, 148, 1-6. [CrossRef] [PubMed]

62. Shen, H.; Xu, W.; Zhang, J.; Chen, M.; Martin, F.L.; Xia, Y.; Liu, L.; Dong, S.; Zhu, Y.G. Urinary metabolic biomarkers link oxidative stress indicators associated with general arsenic exposure to male infertility in a han chinese population. Environ. Sci. Technol. 2013, 47, 8843-8851. [CrossRef]

63. Eliasson, R. Biochemical analysis of human semen. Int. J. Androl. 1982, 128, 1144.

64. Concha, G.; Vogler, G.; Nermell, B.; Vahter, M. Intra-individual variation in the metabolism of inorganic arsenic. Int. Arch. Occup. Environ. Health 2002, 75, 576-580. [CrossRef]

65. Carlin, D.J.; Naujokas, M.F.; Bradham, K.D.; Cowden, J.; Heacock, M.; Henry, H.F.; Lee, J.S.; Thomas, D.J.; Thompson, C.; Tokar, E.J.; et al. Arsenic and Environmental Health: State of the Science and Future Research Opportunities. Environ. Health Perspect. 2016, 124, 890-899. [CrossRef]

66. Gagnon, C. The role of environmental toxins in unexplained male infertility. Semin. Reprod. Med. 1988, 6, 369-376. [CrossRef]

67. Concha, G.; Vogler, G.; Lezcano, D.; Nermell, B.; Vahter, M. Exposure to inorganic arsenic metabolites during early human development. Toxicol. Sci. 1998, 44, 185-190. [CrossRef]

68. Fort, M.; Cosín-Tomás, M.; Grimalt, J.O.; Querol, X.; Casas, M.; Sunyer, J. Assessment of exposure to trace metals in a cohort of pregnant women from an urban center by urine analysis in the first and third trimesters of pregnancy. Environ. Sci. Pollut. Res. 2014, 21, 9234-9241. [CrossRef] [PubMed]

69. Bloom, M.S.; Neamtiu, I.A.; Surdu, S.; Pop, C.; Anastasiu, D.; Appleton, A.A.; Fitzgerald, E.F.; Gurzau, E.S. Low level arsenic contaminated water consumption and birth outcomes in Romania-An exploratory study. Reprod. Toxicol. 2016, 59, 8-16. [CrossRef] [PubMed] 